\title{
Sistem Hukum dan Teori Hukum Chaos
}

\author{
Legal System and Legal Chaos Theory
}

\author{
Amir Syarifudin dan Indah Febriani \\ Fakultas Hukum Universitas Sriwijaya \\ Jln. Raya Palembang - Prabumulih KM 32, Ogan Ilir, Sumatera Selatan. \\ Tel./Fax:+62-711-580169E-mail: amir_syarifudin53@yahoo.co.id
}

Submitted: Jun 12, 2015; Reviewed: Jul 2, 2015; Accepted: Jul 20, 2015

\begin{abstract}
Order of the universe and other objects can be described either by cosmology and physics. But from of the regularity of the object there in terms or aspect of irregularity or fractal (broken) that difficult to describe by Auklides and Calculus mathematical models. Benoit Medelbrot tried to explain the chaotic objects with fractal theory which basically a branch of mathematics. The fractal theory affect the view of the law that inspired Charles Sampford which then sparked a legal chaos theory. The core of legal chaos theory is (1) social relationships, including the relationship established based on the relationship of forces (power relation), (2) the parties who make that relationship does not have the same strength or balance, and (3) at the time of execution of the respective relations based on their subjective opinions. Those three thing that is causing chaos. But the atmosphere of chaos that would eventually return to the regularity, because of the strength towing (strange attractor) that in the area of law is the law and the power of the state. Chaos basically contained in the freedom-based relationship beyond the confines of order. When the towing force managed to recover the chaos so as to create harmony between order and freedom, the peace that one of the legal goal is achieved.
\end{abstract}

Keywords: Chaos; State Power; Order; Peace; Power Relations; Strength Attractor

Abstrak: Keteraturan alam semesta dan objek lainnya dapat dideskripsikan baik oleh kosmologi maupun fisika. Namun dari keteraturan objek itu terdapat segi atau aspek ketidakteraturan atau fraktal (patah) yang sulit dideskripsikan oleh matematika model Auklides dan Kalkulus. Benoit Medelbrot mencoba menjelaskan objek kacau tersebut dengan teori Fraktal yang pada dasarnya merupakan cabang dari matematika. Teori Fraktal tersebut mempengaruhi pandangan terhadap hukum yang mengilhami Charles Sampford yang kemudian mencetuskan teori hukum chaos. Inti teori hukum chaos ialah (1) hubungan sosial, termasuk hubungan hukum dibentuk berdasarkan hubungan kekuatan (power relation), (2) pihak-pihak yang membuat hubungan itu tidak memiliki memiliki kekuatan yang sama atau seimbang, dan (3) pada waktu pelaksanaan hubungan itu masing-masing mendasarkan pada pendapat mereka secara subjektif. Ketiga hal itulah yang menimbulkan chaos. Akan tetapi suasana chaos itu pada akhirnya akan kembali pada keteraturan karena adanya kekuatan penarik (strange attractror) yang 
dalam dunia hukum adalah hukum dan kekuasaan negara. Kekacauan (chaos) pada dasarnya terdapat pada hubungan yang berbasis kebebasan yang melewati batas-batas ketertiban. Bila kekuatan penarik berhasil memulihkan kekacauan itu sehingga tercipta keserasian antara ketertiban dan kebebasan maka tercapai kedamaian yang merupakan tujuan hukum.

Kata Kunci: Hubungan Kekuatan; Kekuasaan Negara; Kedamaian; Kekacauan; Kekuatan Penarik; Keteraturan

\section{PENDAHULUAN}

Sistem adalah suatu keseluruhan yang terdiri dari beberapa bagian (subsistem) dan antara sub sistem-sub sistem itu mempunyai hubungan satu sama lainnya maupun hubungan antara sub sistem dengan keseluruhan (sistem). ${ }^{1}$ Pada umumnya suatu sistem termasuk sistem hukum, dibangun dari objek yang memiliki keteraturan. Objek kajian (gegenstand) ilmu yang merupakan objek empiris $^{2}$ dapat berupa objek fisik maupun non fisik. Objek-objek tersebut pada umumnya memiliki keteraturan, namun demikian pada objek itu juga terdapat segi ketidakteraturan (chaos).

Teori-teori yang dibangun berbasis pada objek teratur itu merupakan ilmu normal. ${ }^{3}$ Bila objek yang hendak dijelaskan

1 A.M. Bos menyebut sebagai suatu a structural whole yang mengandung elemen-elemen (1) the divission of system, (2) the consistency of system, (3) the completeness of system, (4) fundamental concept of the system. Lihat, HAS Natabaya. (2006). Sistem Peraturan Perundang-Undangan di Indonesia. Jakarta: Sekretariat Jenderal dan Kepaniteraan Mahkamah Konstitusi Republik Indonesia, hlm. 8

2 Objek empiris adalah objek yang ada (ens, on, being) yang dapat dialami, artinya objek itu dapat diketahui melalui panca indera manusia.

3 Ilmu normal merupakan istilah yang dipergunakan oleh Thomas Kuhn Samuel dalam bukunya "The Structure of Scienstific Revolution”. Teori-teori yang dibangun atas dasar kerangka asumsi atau model yang dikenal dengan istilah paradigma. Bila suatu teori tidak dapat menjelaskan suatu realitas maka menurut Kuhn paradigma ilmu itu telah ketinggalan zaman dan karena itu perlu disepakati paradigma baru dari para ahli untuk menggantikan paradigma lama. Keadaan dimana paradigm lama atau dideskripsikan oleh suatu teori adalah objek yang tidak teratur atau kacau (chaos) maka teori tersebut akan mengalami kesulitan dalam mendeskripsikannya, dan karena itulah diperlukan paradigma baru untuk menjelaskan objek yang kacau tersebut.

Benoit Mandelbrot (1924-2010) seorang matematikawan Prancis, mengintrodusir teori baru yang disebutnya teori fraktal yang dirancang khusus untuk mendeskripsikan objek fisik yang kacau tersebut dalam ilmu fisika. Teori fraktal itu mengilhami Charles Sampford mengintrodusir teori fraktal di bidang hukum. Teori fraktal di bidang hukum dinamakan teori hukum chaos yang dianggapnya mampu mendeskripsikan ketidakanteraturan hukum itu. Uraian di bawah ini mencoba melihat latar belakang teori fraktal dalam fisika dan pengaruhnya terhadap teori hukum chaos.

\section{ANALISIS DAN PEMBAHASAN}

\section{Paradigma Sistem dan Mekanistik}

Pemikiran sistem sebelum tahun 1930-an dirumuskan oleh para biolog organistik, psikolog gestalt, dan para ekolog yang menuntun para ilmuan berpikir dalam keterkaitan, hubungan-hubungan, dan konteks dan kemudian didukung pula oleh penemuan di bi-

tidak dapat lagi menjelaskan realitas, maka ilmu itu memasuki apa yang disebut "situasi masalah" atau anomali. Jika paradigma lama ditinggalkan dan Hdigantikan dengan paradigma baru, maka terjadilah apa yang disebut Kuhn dengan istilah "revolusi sains". 
dang fisika kuantum ${ }^{4}$. Pemikiran sistem atau ekologi berbeda secara signifikan dengan pemikiran mekanistik ala Cartesian dan Newtonian. Pemikiran mekanistik beranggapan bahwa perilaku keseluruhan hanya dapat difahami dengan menganalisis sifat-sifat bagian-bagiannya. Sebaliknya, pemikiran sistem percaya bahwa semua sistem yang hidup tidak dapat difahami melalui analisis terhadap bagian-bagian. Bagian hanya dapat difahami dalam konteks keseluruhan. Sifatsifat bagian bukan sifat instrinsik, sehingga bagian hanya dapat difahami dalam konteks keseluruhan.

Dalam pemikiran mekanistik hubungan atau relasi antara bagian-bagian dengan bagian-bagian lainnya, antara bagian dengan keseluruhan, bersifat sekunder, sedangkan dalam pemikran sistem maka hubungan atau relasi itulah merupakan hal yang primer. Dengan demikian, setiap objek pada dasarnya terletak dalam sistem jaringan atau hubungan yang lebih besar. Pandangan dunia (paradigma) sistem tersebut bukan saja mempengaruhi pandangan kita terhadap alam semesta akan tetapi mempengaruhi pandangan tentang pengetahuan ilmiah.

4 Fisika Kuantum adalah cabang Fisika dasar yang menggantikan Fisika klasik. Bila Fisika klasik beranggapan bahwa energi itu bersifat sinambung (terus menerus), maka Fisika kuantum berpendapat bahwa energi itu tidak kontinyu, diskrit, paket, atau kuanta (jumlah). Pandangan ini dikemukakan oleh Max Planck pada tahun 1900 dan ini merupakan pandangan yang revolusioner. Dalam hukum pandangan ini menjadi sumber hasrat ingin lebih dari segi jumlah (kuanta) maupun mutu (kualitas) yang pada akhirnya menelorkan nilai Konservatisme (kuanta) dan inovatisme (kualitas). Lihat Purnadi Purbacara dan Soerjono Soekanto. Ikhtisar Antinomi Nilai Sebagai Landasan Filsafat Hukum. Lihat juga Fritjop Capra. Jaring-Jaring Kehidupan Visi Baru Epistimologi dan Kehidupan. Yogyakarta: Fajar Baru, 2002. hlm. 59
Bahwa sistem jaringan dalam paradigma sistem telah diakui oleh para ahli seperti Einstein, Werner Heisenberg, dan Geoffrey Chew 5 .

Dari filsafat Bootstrap dari Geoffrey Chew, jagat raya dipandang sebagai jaringan atau hubungan, alam tidak dapat diprediksi menjadi entitas pokok seperti balok-balok materi bangunan, tetapi harus difahami secara menyeluruh sebagai suatu jaringan. Bila paradigma mekanistik memandang alam sebagai balok balok bangunan yang dapat difahami dengan menganalisis masing masing balok itu, apakah pandangan itu dapat digunakan mendeskrisikan balok balok yang tidak teratur, kacau, atau patah? Ketidakteraturan hanya dapat difahami dengan menganalisis jaringan sebagaimana dikemukan oleh paradigma sistem.

\section{Teori Fraktal}

Bermula dari objek fisik beberapa bendabenda di alam semesta yang menunjukan struktur fraktal $($ fractus $=$ patah) seperti awan, gunung, jaringan sungai, sistem pembuluh darah, turbulensi, garis pantai, pohon, dan lain-lain. Menurut Helge von Koch benda-benda tersebut sulit dideskripsikan dengan menggunakan geometri klasik seperti geometri Euklides dan Kalkulus. Benoit Mandelbrot pada tahun 1975 mencoba mengembangkan geormetri fraktal yang merupakan cabang dari matematika, untuk mengatasi kelemahan geometri klasik tersebut. Namun sebelum Mandelbrot, telah dipelajari oleh Karl Theodor Wilhem Weierstross pada tahun 1872. Juga pada tahun 1914 Helge von Koch yang juga tidak puas pada teori

\footnotetext{
Ibid., hlm 62
} 
Weierstross tersebut mengembangkan teori baru yang disebutnya teori bunga salju Koch. Sebelum Koch, Paul Pierre Levi pada tahun 1938 telah membahas hal ini dalam teorinya curva levic dalam tulisannya "Plane or Space Curve and Services Consisting of Parts Simmiliar to Whole." 6

Pada awalnya, teori Chaos berkembang dalam ilmu fisika yang berlandaskan pada faham materialisme. Alam semesta dipandang sebagai sebuah mesin mekanik yang tersusun atas komponen-komponen materiel yang bergerak dan terhubung secara deterministik. Paradigma mekanistis memandang alam semesta tampak teratur dan terprediksi yang diatur oleh gaya dan kaedah yang bekerja secara mekanistis. Alam semesta bekerja seperti jam raksasa yang bekerja secara otomatis.

Pandangan alam semesta yang mekanisitik ala cartesian dan newtonian tersebut mengalami krisis paradigma pada abad ke-20. Ada dua teori yang menggoyangkan paradigma mekanistis itu, yaitu (1) teori relativitas Einstein, yang menjelaskan gravitasi, kosmologi, dan fenomena makro lainnya, (2) teori kuantum yang menjelaskan partikel sub-atomik yang tidak dapat lagi dideskripsikan secara mekanistik. Kedua teori ini membuktikan keterbatasan paradigma mekanistik itu, walaupun harus diakui bahwa paradigma ini telah berhasil membangun ilmu pengetahuan dan teknoplogi seperti yang kita nikmati sekarang ini.

Alam semesta tidak seluruhnya teratur dan terprediksi, tetapi di dalamnya terdapat ketidakteraturan, chaos, tingkah laku

$6 \quad$ Wikipedia. Available online at: www.id.wikipedia. org/wiki/praktal. Diakses pada tanggal 5 Februari 2015. yang kompleks, irregular, random, bergerak secara acak, non linier, kegelisahan , turbulensi, fluktuatif, dinamis, ketidakpuasan, dan lain-lain. Namun demikian menurut teori chaos, dalam situasi seperti tersebut di atas tetap berada dalam batas-bartas tertentu, artinya chaos itu tidak akan pernah melewati batas-batas tertentu. Pembatas itu dinamakan kekuatan penarik (strange attractor) ${ }^{7}$. Dengan demikian situasi chaos adalah bagian dari suatu ketertiban atau keteraturan, dalam arti keadaan chaos akan kembali pada situasi normal karena adanya strange attractor tadi.

Keteraturan alam semesta serta keteraturan kehidupan bermasyarakat yang merupakan bagian dari alam semesta merupakan dua hal yang menjadi ketakjuban Immanuel Kant selama karir filosofisnya. Dua tema ketakjuban itu, yaitu keteraturan alam semesta dan keteraturan umat manusia oleh muridnya dituliskan pada batu nisan makam nya di Kalininberg, Rusia dengan kalimat " coellum stellatum supra me lex morales intra me" yang artinya langit berbintangbintang diatas saya, hukum moral dalam diri saya. Langit berbintang-bintang menggambarkan keteraturan alam semesta, yang dapat dilihat dari keteraturan planet-planet, bintang-bintang, galaksi-galaksi yang tidak pernah bertabrakan satu sama lainnya. Sedangkan keteraturan manusia dalam hidup bermasyarakat dapat dilihat dari bangunan atau lembaga yang mereka ciptakan serta bangunan hukum yang dijadikan basis penataan masyarakat.

\footnotetext{
Sebagaimana dikutip pada laman website: https:// kelikwardiono.wordpress.com2010/12/28/chaosteori-sebuahancangan-dalammemahamihukum. Diakses tanggal 10 Februari 2015.
} 
Keteraturan bangunan atau lembaga kemasyarakatan maupun lembaga hukum tidak lain didasarkan kepada hukum moral (lex morales) yang terdapat dalam fikiran manusia sehingga ia bisa membedakan dan mengetahui nilai perbuatan yang baik dan mana yang buruk. Baik dalam alam semesta maupun dalam kehidupan masyarakat memang terjadi ketidakteraturan atau chaos, akan tetapi itu hanyalah bagian dari kehidupan dan keadaan itu tetap akan kembali kepada keteraturan karena adanya kekuatan penarik (strange attractor) yang bekerja secara mekanistik pula.

\section{Sistem Hukum}

Apabila hukum dianggap sebagai suatu sistem, maka paling tidak terdapat beberapa faktor yang relevan ${ }^{8}$ : (a) elemen-elemen suatu sistem yaitu unsur-unsur dasar yang membentuk suatu sistem hukum; (b) pembagian sistem, artinya bahwa suatu sistem memiliki sub atau bagian yang membentuk sistem itu; (c) konsistensi, artinya antara bagian/subbagian terdapat kesesuaian atau tidak bertentangan; (d) kelengkapan sistem, artinya adanya suatu bagian yang menjadi pelengkap dari bagian yang pokok; dan e) pengertian-pengertian dasar, artinya setiap suatu sistem memiliki pengertian atau konsep tertentu yang membedakannya dengan pengertian-pengertian yang dimiliki oleh sistem yang lain.

Dengan demikian, sudah jelas bila kita menyebut sistem hukum tersirat di dalamnya tidak mengandung inkonsistensi atau saling bertentangan antara sub/bagian dalam sistem

8 Purnadi Purbacaraka dan Soerjono Soekanto. (1979). Sendi-Sendi Ilmu Hukum dan Tata Hukum. Bandung: Alumni, hlm. 50 itu. Bila terdapat adanya inkonsistensi antara subbagian dan antara subbagian dengan sistem keseluruhan maka ini disebut "sistem yang sakit". Namun karena hukum pada dasarnya merupakan suatu" sistem yang sehat" maka bila terjadi atau terdapat inkonsistensi telah tersedia mekanisme penyelesaian inkonsistensi itu.

Mekanisme dalam mengatasi inkonsistensi itu adalah: 1) penerapan asas-asas perundang-undangan, yaitu (a) hukum yang tertinggi mengeyampingkan hukum yang lebih rendah, (b) hukum yang berlaku kemudian mengenyampingkan hukum yang berlaku terdahulu; 2) pengujian undang-undang baik formil maupun materiel; 3) revisi atau perubahan yang dilakukan oleh pembentuknya (legislative review); 4) penafsiran oleh hakim maupun badan administrasi negara; (5) konstruksi hukum yang dilakukan oleh hakim yang dapat berupa analogi dan penghalusan hukum.

Walaupun hukum merupakan sistem yang teratur dan memiliki mekanisme mengatasi inkonsistensi, terdapat pula aspek ketidak teraturan hukum itu. Dengan demikian ketidakteraturan dapat terjadi pada sikap tindak yang tidak sesuai dengan hukum atau mereka merasa bertindak menurut hak dan kewajiban menurut persepsinya masing-masing. Contoh bentuk-bentuk ketidakteraturan itu di Indonesia dapat berupa prilaku atau sikap tindak kekerasan massa, pengkaplingan tanah tanpa hak, pemagaran atau pemblokiran jalan tol dan jalan raya, pendudukan kantor bupati, pengahncuran lokalisasi WTS, sweeping tempat maksiat dan perjudian, pembantaian dukun santet, bentrok massa, pembunuhan, pembakaran rumah ibadah ali- 
ran yang dianggap sesat, dan lain-lain.

Mempelajari hukum dengan menggunakan pendekatan yuridis-dogmatis yang dianggap sebagai teori keteraturan, dipandang kurang mampu menjangkau keadaankeadaan tersebut di atas. Dalam pendekatan yuridis- dogmatis hukum dipandang sebagai deskripsi dari kenyataan yang sebenarnya, yaitu suatu kenyataan yang penuh keteraturan. Dengan demikian hukum harus dipandang tidak hanya deskripsi dari keteraturan tapi juga harus dipandang dari ketidakteraturannya yang tidak dapat diprediksi dan tidak sistematis.

Pada tahun 1990-an Charles Sampford dalam buku nya "The Disorder of Law", mengkritik teori hukum yang telah mapan seperti yang dipergunakan dalam pendekatan yuridis-dogmatis. Pokok-pokok ajaran Sampford adalah sebagai berikut: (1) ketidakteraturan dan ketidak pastian dalam hubungan sosial, termasuk hubungan hukum dibangun atas dasar hubungan kekuatan (power relation), hubungan kekuatan itu tidak tercermin dalam hubungan formil (hubungan hukum). Dengan demikian terdapat kesenjangan antara hubungan formil dengan hubungan nyata (hubungan kekua$\tan )$. Kesenjangan inilah yang menimbulkan ketidakteraturan (chaos), (2) hubungan dalam masyarakat yang didasarkan pada hubungan kekuatan, dimana masing-masing pihak tidak memiliki kekuatan yang sama akibatnya timbul adu kekuatan dari masingmasing pihak. Keadaan ini menimbulkan keadaan asimetris yang dinamakannya "social melee" suatu hubungan sosial yang cair ( $f l u$ id), (3) setelah hukum ditetapkan oleh penguasa atau oleh pihak-pihak maka hukum itu selanjutnya dilaksanakan oleh pihak-pihak yang tidak memiliki kekuatan yang sama itu memunculkan ketidakteraturan (disorder). Masing-masing pihak membuat putusan yang subjektif, seperti hakim membuat putusan berdarkan kewenangannya, advokat membuat putusan dengan menggali celahcelah kelemahan hukum demi kepentingan kliennya, sedangkan orang awam melihatnya sebagai putusan penguasa. ${ }^{9}$

Menurut teori chaos dunia tidak lagi dapat dilihat secara sepihak menurut konsep keteraturan tetapi juga sekaligus harus dilihat dikotominya, yaitu kekacauan atau disorder. Dengan demikian masyarakat harus dilihat mernurut konsep dikotomi keteraturan atau kekacauan, kesatuan/separatisme, integrasi/ disintegrasi, keseragaman/keanekaragaman, sentralisasi/desentralisasi, homogenitas/heterogenitas. Dengan demikian hukum dilihat secara dualisme (dikotomi) sehingga teori hukum yang dihasilkan dapat mendiskripsikan kenyataan yang sesungguhnya.

\section{Refleksi}

Keteraturan alam semesta, keteraturan masyarakat juga mengandung ketidakteraturan. Adanya pengertian keteraturan, karena kita tahu adanya ketidakteraturan. Analog dengan itu ialah kita mengenal konsep siang karena

9 Bandingkan arti hukum yang diberikan oleh masing masing pihak atau masyarakat sangat beraneka ragam,terlepas dari apakah arti yang diberikan etu benar atau salah. Arti hukum yang pernah diberikan masyarakat antara lain (1) hukum sebagai ilmu pengetahuan,(2) hukum sebagai disiplin,(3) hukum saebagai kaedah,(4)hukum sebagai tata hukum,(5)hukum sebagai petugas,(6)hukum sebagai putusan penguasa,(7)hukum sebagai proses pemerintahan,(8)hukum sebagai perilaku yang ajeg,dan(9)hukum sebagai jalinan nilai. Lihat Purnadi Purbacaraka dan Soerjono Soekanto. Perihal Kaedah Hukum., Op., Cit. Hlm. 4 
adanya konsep malam. Tidak akan ada konsep siang jika orang tidak tahu malam. Secara filosofis, di dalam hukum terdapat nilai yang menggambarkan pasangan-pasangan realitas, sebagaimana digambarkan oleh teori chaos seperti keteraturan/kekacauan, kesatuan/pemisahan, dan lain-lain. Namun pasangan-pasangan itu merupakan nilai kontrair/saling menutupi.

Jika ada keteraturan pasti menutup kekacauan, jika terdapat suasana kacau, pasti tidak ada ketertiban. Menurut pandangan kita, bahwa penggambaran yang demikian kurang realistis. Sesungguhnya yang ada bahwa dalam ketertiban/keteraturan itu terdapat kebebasan. Apabila kebebasan itu melampaui batas itulah yang berpotensi membuat kekacauan. Namun demikian yang realistis adalah ketertiban dan kebebsan, yang keduanya tidak dapat saling menutupi, tetapi saling membatasi dan melengkapi dalam Suasana serasi. Nilai-nilai itu dinamakan nilai antinomi, yaitu nilai-nilai yang berpasang-pasangan, walaupun ada kalanya bertegangan ${ }^{10}$, tetapi saling membatasi. Nilai-nilai antinomi, sebagaimana diuraikan pada Gambar 1. ${ }^{11}$

Nilai itu dikatakan berpasangan karena mereka saling membatasi, saling

10 Ketegangan nilai artinya apabila nilai yang satu mendesak atau menekan nilai pasangan, misalnya nilai ketertiban menekan kebebasan, sehingga orang merasa kebebasannya tertekan, yang wujudnya berupa demo(unjuk rasa), protes pemberontakan, separatisme, dan lain-lain. Dengan demikian diperlukan penyerasian yaitu dengan cara memperkecil nilai yang menekan (ketertiban) dengan memperbesar nilai yang ditekan (kebebasan)

11 Purnadi Purbacaraka dan Sorjono Soekanto. Ikhtisar Antinomi Nilai Aliran Filsafat Sebagai Landasan Filsafat Hukum. Jakarta:Rajawali, Cetakan kedua. hlm. 5 . melengkapi, sehingga dapat terwujud dalam keadaan yang serasi ${ }^{12}$. Di samping berpasang-pasangan, seperti ketertiban dan kebebasan, maka nilai itu berjalinan, artinya pasangan nilai ketertiban dan kebebasan berhubungan erat dengan pasangan nilai kepastian hukum dan kesebandingan hukum. Begitu pula pasangan nilai kepastian hukum dan kesebandingan hukum berjalinan lagi dengan nilai restriksi hukum dan nilai proteksi hukum dan seterusnya.

Jika nilai-nilai yang ada di sebelah kiri diberi nama kutub $\mathrm{A}$, dan nilai disebelah kanan diberi nama kutub $\mathrm{B}$, maka jika nilai kutub A diutamakan (diperbesar) maka konsekwensinya nilai kutub B harus diperkecil, tapi tidak boleh sampai hilang. Keserasian antara kutub A dengan kutub B sangat ditentukan oleh ruang dan waktu. Gambaran keserasian nilai kutub A dan kutub B dapat dilihat pada Gambar 2.

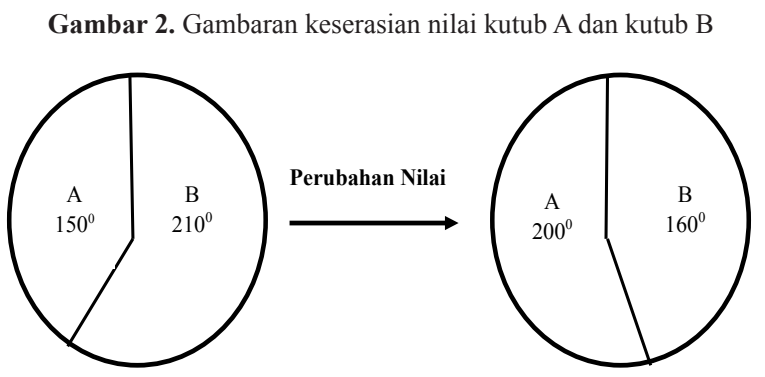

Catatan: Jika nilai kutub A $150^{\circ}$, maka akibatnya nilai kutub B $210^{\circ}$; jika nilai kutub A diperbesar menjadi $200^{\circ}$ maka nilai kutub $B$ harus diperkecil. Tidak bisa nilai kedua kutub sama-sama diperbesar atau sama-sama diperkecil.

12 Keserasian nilai adalah tujuan hukum. Keserasian merupakan pengertian umum (genus), sedangkan pengertian khusus adalah tergantung pada nilai yang bersangkutan. Keserasian antara ketertiban dengan kebebasan disebut kedamaian; keserasian antara kepastian dan kesebandingan disebut keadilan; keserasian antara materialisme dan spiritualisme disebut kesejahteran. Kedamaian, keadilan, dan kesejahteraan adalah tujuan yang hendak dicapai oleh hukum. Lihat Pengabdian Tiga Guru Besar Filsafat Hukum. Jakarta: Djokosoetono Centre, 2013. Hlm. 22 
Gambar 1. Nilai-Nilai Antinomi

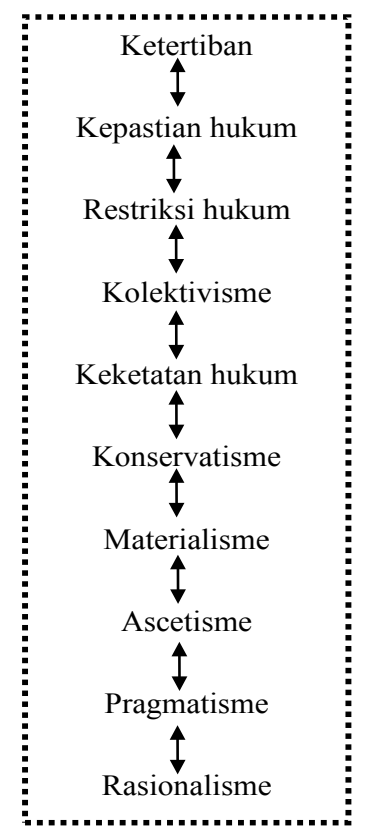

KUTUB A

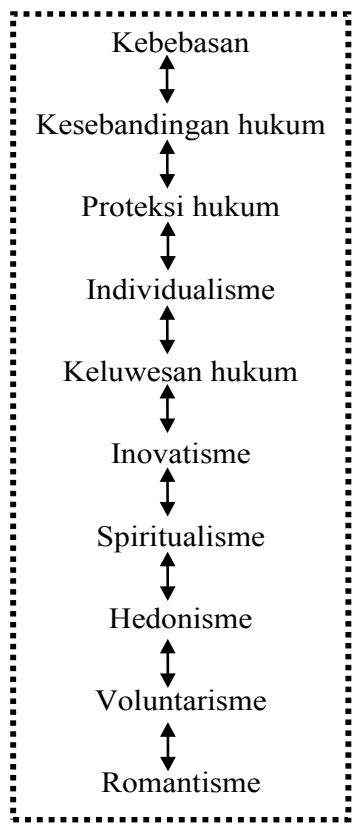

KUTUB B

- Tanda strip (-) menunjukan berpasang-pasangan, artinya kedua nilai itu tidak dapat dipisahkan

- Tanda panah $(\boldsymbol{I})$ menunjukan berjalinan antara dengan nilai di atas atau di
}

Ketertiban yang bermakna dapat diperkirakan (voorspelbaarheit) atau ketaatan (conformiteit) sebagaimana dikemukakan oleh Schuyt ${ }^{13}$. Ketertiban adalah nilai yang dianggap baik, karena pada dasarnya manusia juga ingin hidup tertib. Akan tetapi ketertiban tanpa kebebasan menjadi totaliter seperti robot, oleh karena itu ketertiban tidak boleh mengganggu dan mengekang kebe-

13 Schuyt mengemukakan ciri keadaan tertib sebagai berikut: (1) voorspelbaarheid (dapat diperkirakan), (2) cooperative (kerjasama), (3) controle van geweld (pengendalian kekerasan), (4) consistentie (kesesuaian), (5) duurzaamheid (langgeng), (6) stabiliteit (mantap), (7) hierarchie (berjenjang), (8) comformiteit (ketaatan), (9) afwezigheid van conflict (tanpa perselisihan), (10) uniformiteit (keseragaman), (11) gemeenschappelijkeheid (kebersamaan), (12) regelmaat ( ajeg), (13) bevel (suruhan), (14) volgorde (keberurutan), (15) uiterlijke stijl (corak lahir), dan (16) rangschikking (tersusun). Lihat Purnadi Purbacaraka dan Sorjono Soekanto. (1982). Renungan Tentang Filsafat Hukum. Jakarta: Rajawali Pers, p. 17-18. basan. Kebebasan adalah nilai yang dianggap baik, karena dengan kebebasan orang dapat menikmati hidupnya. Akan tetapi kebebasan tanpa batas, berpotensi mengganggu kebebasan orang lain, akan mengganggu ketertiban. Kebebasan tanpa ketertiban adalah anarkhi.

Dengan demikian, kebebasan itu hanya dapat dicapai dalam suasan yang tertib. Antara ketertiban dan kebebasan bersifat antinomik, artinya ia saling melengkapi, tidak saling menutup. Berbeda dengan ketertiban atau keteraturan dan kekacauan (chaos), dua nilai itu bersifat kontrair, saling menutup, artinya jika ada ketertiban/keteraturan, maka pasti tidak kacau. Sebaliknya, jika terdapat kekacauan pasti tidak tidak tertib. Analog dengan pengertian tersebut seperti konsep siang dan malam, karena bersifat kontrair, 
saling menutup. Jika siang, maka pasti tidak malam, dan sebaliknya jika malam pasti tidak siang. Tidak mungkin terjadi keserasian antara siang dan malam atau ketertiban dengan kekacauan. Konsep antinomik hanya terdapat pada nilai yang saling mengisi dan saling membatasi (nilai antinomi), tidak terdapat pada nilai yang saling menutup dan kontrair.

Sebagaimana dikemukakan Sampford bahwa kekacauan atau chaos yang disebabkan oleh hubungan (relasi) antara pihak didasarkan pada kekuatan (power) yang tidak seimbang. Akan tetapi ketidakseimbangan itu bersifat sementara, ia akan kembali kepada suasan tertib/teratur. Hal itu terjadi karena baik dalam alam semesta maupun kehidupan sosial, terdapat kekuatan penarik (strange attractor) yang mendorong terjadi keteraturan atau ketertiban itu. Kekuatan penarik gaya dalam alam semesta terdapat gaya nuklir kuat atau lemah dan gravitasi. Sedang dalam bidang sosial terdapat kekuatan (power) atau kekuasaan (macht, power, kraft). Kekuatan itu mewujudkan diri dalam hukum dan kekuasaan negara. ${ }^{14}$ Hukum dan kekuasaan negara adalah dua lembaga yang memiliki kemampuan menarik suasana chaos kepada ketertiban.

Secara antinomi, kekacauan itu adalah berbasis pada kebebasan yang ditafsirkan secara subjektif oleh masing-masing pihak.

14 Kekuatan dalam masyarakat itu mewujudkan diri dalam dua lembaga yaitu (1) lembaga penata masyarakat secara normatif (lembaga hukum), dan (2) lembaga penata masyarakat secara efektif, yang mampu bertindak (lembaga kekuasaan). Kekuasaan (negara) dijalankan/dilaksanakan atas landasan hukum, sebaliknya hukum dilaksanakan dan ditegakkan oleh kekuasaan. Lihat Frans Magnis Suseno. (1984). Etika Politik. Jakarta: Gramedia Pustaka Utama, hlm. 70
Akan tetapi kekacauan yang dikonsepkan oleh Sampford itu tetap tidak boleh melampaui batas ketertiban. Kekuatan penjaga ketertiban itu yang dinamakan kekuatan penarik (strange attractor) adalah kekuasaan (negara). Kekuasaan negara itu juga berpotensi membuat kekacauan jika tidak dibatasi dan dilandasi oleh hukum. Sisi lemah dari hukum yang membatasi kekuasaan negara itu adalah hukum itu dilaksanakan dan ditegakkan oleh kekuasaan. Hukum tanpa kekuasaan negara adalah lumpuh, tidak ada kekuatan yang dapat menegakkan hukum.

Kecenderungan umum adalah kekuasaan itu cenderung melanggar hukum ${ }^{15}$. Agar kekuasaan tidak melanggar hukum, maka kekuasaan itu harus diwasi oleh kekuasaan lain dalam posisi yang seimbang, yang dikenal dengan konsep "Checks and Balances"16 seperti yang diterapkan dalam konstitusi Amerika dan juga telah diadopsi oleh UUD 1945 pada perubahan ke- $3^{17}$.

15 Tesis Lord Acton: "Power tends to corrupt, absolute power corrupt absolutely" telah dijadikan semacam postulat yang dijadikan premis dalam kehidupan masyarakat modern.

16 Konsep Checks and Balances bermula pada konsep pengendalian (cybernetic) yang dikemukakan oleh Nobert Wiener yang banyak dipergunakan oleh ilmu sosial seperti konsep "Invisible Hand" Adam Smith, "Check and Balances" dalam Konstitusi Amerika, "tesis-antitesis" dalam dialektika Hegel. Lihat Fritjop Capra., Op., Cit. Hlm 97

17 Check and Balances adalah konsep pengendalian kekuasaan agar tidak bertindak lebih, melanggar hukum. Kekuasaan negara dipisah menjadi kekuasaan legislatif, eksekutif, dan judisial. Masing-masing kekuasaan itu dipegang oleh satu subjek hukum dan meraka saling mengawasi (checks), lembaga lainnya dalam posisi seimbang (balances). Konsep ini dapat dilihat dalam pengawasan DPR terhadap presiden. Pengawasan produk undang-undang oleh Mahkamah Konstitusi, pengawasan pada halim oleh Komisi Yudisial, pengawasan peraturan perundang-undangan di bawah undang-undang oleh Mahkamah Agung. 
Adanya kekuasaan yang melewati batas merupakan dasar kekacauan. Dengan demikian kebebasan yang tanpa batas, melewati batas ketertiban harus dibawa ke arah ketertiban, baik melalui peradilan maupun tindakan pemerintahan.

Keadaan yang tidak terduga dan tidak terprediksi juga telah diantisispasi oleh hukum. Keadaan darurat ${ }^{18}$, bencana alam, gempa bumi, kepentingan memaksa, perang, kerusuhan telah disediakan perangkat hukum dalam bentuk hukum darurat, Peraturan Pemerintah Pengganti Undang-Undang ${ }^{19}$, keadaan bahaya ${ }^{20}$. Keberlakuan suatu undang-undang juga telah menyediakan aturan penyimpangan yang mencakup pembenaran dan bebas kesalahan (pemaafan) untuk keadaan "overmacht", "noodtoestand"21. Antisipasi hukum terhadap keadaan sebagaimana tersebut di atas pada intinya untuk menanggulangi keadaan kacau untuk menuju ke arah keteraturan/ketertiban.

\section{PENUTUP}

Sistem hukum pada umumnya dibangun berdasarkan realitas yang teratur, realitas yang tertib, dan menghasilkan teori hukum yang teratur seperti teori hukum positif yang menggunakan pendekatan yuridis dogmatis. Akan tetapi, dalam keteraturan/ketertiban alam semesta dan masyarakat terdapat segi/ dimensi kekacauan (chaos). Dari dimensi re-

18 Lihat Undang-Undang darurat Nomor 12 Tahun 1951 tentang Mengubah Ordonantietijdellijke Bozondere Strafbepalingen (Stbl 1940 No. 17) dan Undang-Undang Indonesia Dahulu No. 8 Tahun 1948.

19 Lihat UUD NRI 1945 Pasal 22

20 Lihat UUD NRI 1945 Pasal 12

21 Purnadi Purbacaraka dan Soerjono Soekanto. (1983). Perihal Kaedah Hukum. Bandung: Citra Aditya Bakti, hlm. 60 alitas kacau seperti tersebut di atas itu, dibangunlah suatu teori untuk mendeskripsikan realitas tersebut, seperti teori Fraktal dalam fisika, dan teori keos dalam hukum.

Menurut Charles Sampford, realitas chaos dalam dunia hukum disebabkan oleh hubungan sosial, dibangun oleh manusia didasarkan pada hubungan kekuatan (power relation) yang tidak seimbang. Sewaktu mereka meralisasikan/melaksanakan hubungan itu, berdasarkan pada kekuatan mereka masing-masing dan inilah sumber dari kekacauan itu. Akan tetapi pencetus teori Chaos meyakini bahwa kekacauan itu sifatnya tidak permanen, ia akan kembali kepada keadan normal/keteraturan. Terdapat suatu kekuatan penarik (strage attractor) yang mendorong kembali keadaan kacau (chaos) pada keadaan teratur. Kekuatan atau tenaga penarik itu dalam alam semesta seperti gaya nuklir kuat, gaya nuklir lemah, gaya elektromagnetik, dan gaya gravitasi. Kekuatan penarik dalam hubungan sosial adalah kekuatan dalam masyarakat yang menurut Magnis Suseno menjelma dalam dua lembaga penata masyarakat secara normatif (lembaga hukum) dan lembaga penata masyarakat yang mampu bertindak (kekuasaan negara). Hukum dan kekuasaan negara itulah yang menarik keadaan kacau kepada keadaan tertib.

Dari segi filsafat, ketertiban/keteraturan merupakan nilai yang berpasangan dengan kebebasan. Kebebasan yang tanpa ketertiban itulah yang menimbulkan chaos. Oleh karena itu keadaan chaos akan ditarik kekuatan penarik (strange power) pada situasi teratur/tertib. Jika kebebasan itu tidak melewati batas ketertiban, maka terciptlah kedamaian, yaitu suatu keadaan yang ingin 
dicapai oleh hukum. Dengan perkataan lain kedamaian adalah tujuan hukum.

\section{BIBLIOGRAFI}

Frans Magnis Suseno. (1984). Etika Politik. Jakarta: Gramedia Pustaka Utama.

Fritjop Capra. (2002). Jaring-Jaring Kehidupan Visi Baru Epistimologi dan Kehidupan. Yogyakarta: Fajar Baru.

H.A.S Natabaya. (2006). Sistem Peraturan Perundang-Undangan di Indonesia. Jakarta: Sekretariat Jenderal dan Kepaniteraan Mahkamah Konstitusi Republik Indonesia.

Pengabdian Tiga Guru Besar Filsafat Hukum. Jakarta: Djokosoetono Research Centre, 2013.

Purnadi Purbacaraka dan Soerjono Soekanto. (1979). Sendi-Sendi Ilmu Hukum dan Tata Hukum. Bandung: Alumni.
Purnadi Purbacaraka dan Soerjono Soekanto. (1982). Renungan Tentang Filsafat Hukum. Jakarta: Rajawali Pers. (1983). Perihal Kaedah Hukum. Bandung: Citra Aditya Bakti. (2002). Ikhtisar Antinomi Nilai Aliran Filsafat sebagai Landasan Filsafat Hukum. Cetakan kedua. Jakarta: Rajawali.

Sumber lainnya:

Laman website: https://kelikwardiono.wordpress.com2010/12/28/chaos-teorisebuahancangan-dalammemahami hukum. Diakses tanggal 10 Februari 2015.

Wikipedia. Available online at: $\underline{w w}$. id.wikipedia.org/wiki/praktal. Diakses pada tanggal 5 Februari 2015. 